Article

\title{
Esterification of cyclohexene with formic acid over a peanut shell-derived carbon solid acid catalyst
}

\author{
Wei Xue, Hepan Zhao, Jie Yao, Fang Li *, Yanji Wang \# \\ Hebei Provincial Key Lab of Green Chemical Technology and High Efficient Energy Saving, School of Chemical Engineering and Technology, \\ Hebei University of Technology, Tianjin 300130, China
}

A R T I C L E I N F 0

Article history:

Received 21 December 2015

Accepted 26 February 2016

Published 5 May 2016

\section{Keywords:}

Carbon solid acid

Peanut shell

Cyclohexene

Esterification

Cyclohexyl formate

\begin{abstract}
A B S T R A C T
A carbon solid acid catalyst was prepared by the sulfonation of partially carbonized peanut shell with concentrated $\mathrm{H}_{2} \mathrm{SO}_{4}$. The structure and acidity of the catalyst were characterized by Fourier transform infrared spectroscopy, scanning electron microscopy, X-ray diffraction, thermogravimetric analysis, X-ray photoelectron spectroscopy, and elemental analysis, which showed that it was an amorphous carbon material composed of aromatic carbon sheets in random orientations. Sulfonic acid groups were present on the surface at a density of $0.81 \mathrm{mmol} / \mathrm{g}$. The carbon solid acid catalyst showed better performance than HZSM-5 for the esterification of cyclohexene with formic acid. At a 3:1 molar ratio of formic acid to cyclohexene, catalyst loading of $0.07 \mathrm{~g} / \mathrm{mL}$ of cyclohexene, and reaction time of $1 \mathrm{~h}$ at $413 \mathrm{~K}$, the cyclohexene conversion was $88.4 \%$ with $97.3 \%$ selectivity to cyclohexyl formate. The carbon solid acid catalyst showed better reusability than HZSM- 5 because its large pores were minimally affected by the accumulation of oligomerized cyclohexene, which deactivated HZSM-5. The activity of the carbon solid acid catalyst decreased somewhat in the first two recycles due to the leaching of polycyclic aromatic hydrocarbon containing $-\mathrm{SO}_{3} \mathrm{H}$ groups and then it remained constant in the following reuse.
\end{abstract}

(c) 2016, Dalian Institute of Chemical Physics, Chinese Academy of Sciences. Published by Elsevier B.V. All rights reserved.

\section{Introduction}

In recent years, carbon solid acids (CSAs) have been studied by many researchers [1-21]. CSAs are amorphous carbon materials consisting of small polycyclic aromatic carbon sheets with attached $\mathrm{SO}_{3} \mathrm{H}$ groups [1]. Due to the high density of $\mathrm{SO}_{3} \mathrm{H}$ groups, simple separation process and environmentally friendly characteristics, CSAs are considered promising replacements for $\mathrm{H}_{2} \mathrm{SO}_{4}$, which is one of the most widely used liquid acid catalysts for the production of many industrially important chemicals [2]. CSAs exhibit high catalytic performance for many types of acid-catalyzed reactions, such as esterification [3-7], transesterification [8-10], hydration [2,11], dehydration [12], alkylation [13], hydrolysis [14-17], condensation [18], and rearrangement $[19,20]$. There are two routes for the preparation of CSAs [21]: one is the incomplete carbonization of sulfoaromatic compounds and the other is the sulfonation of partially carbonized organic matter, such as sucrose, D-glucose, starch, cellulose, or biomass. Most CSAs are prepared by the second route because of its convenience and safety.

Peanut shell is an agricultural waste and would be an excellent bio-resource for preparing CSAs because of its high supply,

\footnotetext{
* Corresponding author. Tel: +86-22-60203540; Fax: +86-22-60204697; E-mail: lifang@hebut.edu.cn

\# Corresponding author. Tel: +86-22-60202419; Fax: +86-22-60204697; E-mail: yjwang@hebut.edu.cn

This work was supported by the National Natural Science Foundation of China $(21236001,21176056)$, the Programme for 100 Excellent Talents in Universities of Hebei Province (II) (BR2-208), and the Natural Science Foundation of Hebei Province (B2015202228).

DOI: 10.1016/S1872-2067(15)61076-2 | http://www.sciencedirect.com/science/journal/18722067 | Chin. J. Catal., Vol. 37, No. 5, May 2016
} 
low cost, and easy sustainability. Several papers [22-24] have reported the preparation of CSAs by the sulfonation of the partially carbonized peanut shell and shown their high activity and excellent recyclability for biodiesel production and esterification reactions. Zeng et al. [24] found that the acid strength of the CSAs from peanut shell was stronger than that of HZSM-5 $(\mathrm{Si} / \mathrm{Al}=75)$, but weaker than that of $100 \% \mathrm{H}_{2} \mathrm{SO}_{4}$. The CSAs produced from peanut shell do not have any Lewis acid sites on their surface.

Cyclohexyl formate is an important chemical used in the perfume and coating industries [25]. The most widely used method for the production of cyclohexyl formate is the reaction of formic acid with cyclohexanol over a mineral acid catalyst or an acidic heterogeneous catalyst. Due to the availability of cyclohexene on a large scale, the direct esterification of cyclohexene with formic acid has been of interest in recent years. Saha et al. [26] investigated the esterification of formic acid with cyclohexene in the presence of cation-exchange resins as the catalyst. Cyclohexene conversion reached $95.7 \%$ with 95.2\% selectivity for cyclohexyl formate. The esterification of cyclohexene with acetic acid has been also studied over $\mathrm{H} \beta$ [27], ionic liquids [28], and ion exchange resins [25]. A propysulfonic acid modified mesostructured silica (SBA-15- $\mathrm{SO}_{3} \mathrm{H}$ ) was used as catalyst for the esterification of acrylic acid and cyclohexene [29], which gave good catalytic performance and stability. Other than use in the perfume industry, cyclohexyl formate can also be easily hydrolyzed to cyclohexanol [30], which is an important chemical intermediate in the synthesis of adipic acid and caprolactam for the production of nylon- 6 and nylon-66 polymers [31]. In the 1990s, Asahi Chemical Industry Co. commercialized a process for the preparation of cyclohexanol by the direct hydration of cyclohexene [32]. However, this reaction is limited by the thermodynamics and extremely poor miscibility of water and cyclohexene, and the reaction rate was low. The once-through yield was only $10 \%$, which led to high recycle amounts with high energy consumption. The synthesis of cyclohexanol from cyclohexene via cyclohexyl formate in the direct hydration of cyclohexene overcomes the drawbacks above [33]. Steyer et al. [30] studied the esterification of cyclohexene with formic acid and the subsequent hydrolyzation of the ester over Amberlyst 15 catalyst in a reactive distillation column. They concluded that it was possible to achieve an almost complete conversion of cyclohexene to cyclohexanol [34]. Du et al. [35] studied the one-pot synthesis of cyclohexanol from cyclohexene via cyclohexyl formate over HZSM-5 catalyst and obtained cyclohexanol in yields of up to $40 \%$, which was far more than in the direct hydration of cyclohexene.

Concerning the two reactions in the synthesis of cyclohexanol from cyclohexene via cyclohexyl formate, the esterification of cyclohexene with formic acid should receive more attention because the hydrolyzation of cyclohexyl formate is much easier. Cyclohexyl formate conversion can reach nearly $60 \%$ with high cyclohexanol selectivity even without a catalyst [35]. Therefore, in this work, the catalytic performance of a CSA catalyst for the esterification of cyclohexene with formic acid was evaluated. The CSA catalyst was prepared by the sulfonation of partially carbonized peanut shell with concentrated $\mathrm{H}_{2} \mathrm{SO}_{4}$. The struc- ture and acidic properties were characterized and the reusability of the catalyst was also studied.

\section{Experimental}

\subsection{Catalyst preparation}

Peanut shell was heated in a tube furnace for $10 \mathrm{~h}$ at $723 \mathrm{~K}$ under a $\mathrm{N}_{2}$ flow. Then the partially carbonized peanut shell was ground into powder. To sulfonate this carbon material, $6 \mathrm{~g}$ of the carbonized peanut shell powder and $150 \mathrm{~mL}$ concentrated $\mathrm{H}_{2} \mathrm{SO}_{4}$ (98\%) were mixed in a $250 \mathrm{~mL}$ flask and heated at $433 \mathrm{~K}$ for $8 \mathrm{~h}$ under $\mathrm{N}_{2}$ flow. After sulfonation, the mixture was cooled to room temperature. Then the carbon material was filtered and washed repeatedly with hot deionized water (>353 K) until the filtrate was free of $\mathrm{SO}_{4}{ }^{2-}$. Finally, the solid was dried at $353 \mathrm{~K}$ under vacuum overnight to obtain the peanut shell derived carbon solid acid catalyst. The catalyst was denoted as PSCSA.

\subsection{Catalyst characterization}

The Fourier transform infrared (FT-IR) spectrum of PSCSA with the $\mathrm{KBr}$ tablet method was recorded by a Thermo Nicolet Nexus 470 spectrometer. The results were used to determine the functional groups on the material. The morphology of PSCSA was characterized by scanning electron microscopy (SEM) using a Hitachi S-4800 field emission scanning electron microscope. X-ray diffraction (XRD) was carried out using a Rigaku D/Max-2500 X-ray diffractometer and $\mathrm{Cu} K_{\alpha}$ radiation at $40 \mathrm{kV}$ and $100 \mathrm{~mA}$. Raman spectra were measured by a Renishaw inVia Reflex microspectrometer.

The thermostability of PSCSA was measured by thermogravimetric analysis (TGA) using a DuPont TA2000 TG analyzer. The temperature was increased from ambient temperature to $1273 \mathrm{~K}$ under air/ $\mathrm{N}_{2}$ flow at a heating rate of $10 \mathrm{~K} / \mathrm{min}$. $\mathrm{X}$-ray photoelectron spectroscopy (XPS) measurements were performed with a PE PHI-1600 spectrometer with a Mg $K_{\alpha}$ source $(1253.6 \mathrm{eV})$. The composition of the samples was determined by the elemental analysis of $\mathrm{C}, \mathrm{H}, \mathrm{N}, \mathrm{S}$ and $\mathrm{O}$ using an Elementar Vario EL elemental analyzer. The content of $\mathrm{S}$ was used to calculate the acid density of $-\mathrm{SO}_{3} \mathrm{H}$. The specific surface area and pore structure of PSCSA were measured by $\mathrm{N}_{2}$ adsorption using a Micromeritics ASAP 2020 instrument. The surface area was calculated by the BET method.

\subsection{Catalytic activity test}

The esterification of cyclohexene with formic acid was carried out in a 100-mL Teflon-lined stainless steel autoclave fitted with a magnetic stirrer. In a typical experiment, $15.0 \mathrm{~mL}$ cyclohexene ( $0.148 \mathrm{~mol}$ ) and $16.8 \mathrm{~mL}$ formic acid ( $0.446 \mathrm{~mol})$ were introduced into the autoclave together with 1.05 g PSCSA as catalyst. The autoclave was sealed and pressurized with $\mathrm{N}_{2}$ for leak testing, then purged and the temperature set to $413 \mathrm{~K}$ to start the esterification. At the end of the reaction, the autoclave was cooled in an ice bath and vented. The catalyst was sepa- 


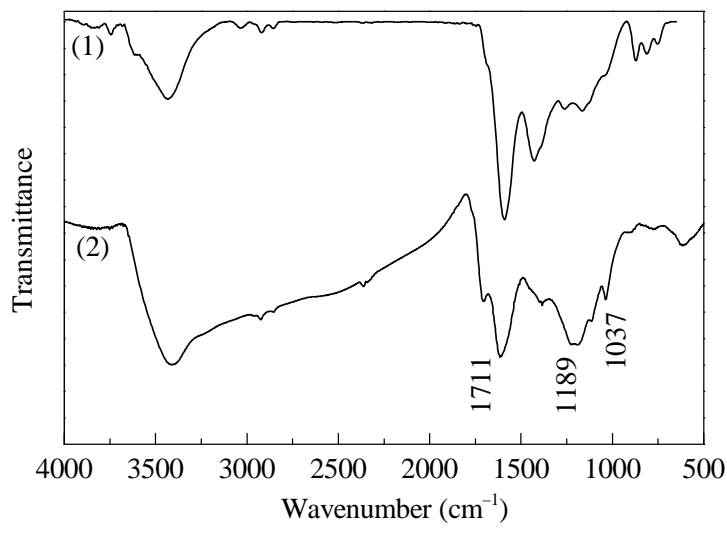

Fig. 1. FT-IR spectra of partially carbonized peanut shell (1) and PSCSA (2).

rated by centrifugation and the liquid was washed with deionized water to eliminate formic acid. The reaction products in the organic phase were identified and quantified by capillary gas chromatography using a BAIF SP-3420 instrument with PEG 20M column (30 $\mathrm{m} \times 0.25 \mathrm{~mm})$ and FID. Cyclohexene conversion $(X)$ and cyclohexyl formate selectivity $(S)$ were calculated by

$$
\begin{gathered}
X=\frac{\text { moles of converted cyclohexene }}{\text { moles of initial cyclohexene }} \times 100 \% \\
S=\frac{\text { moles of cyclohexyl formate formed }}{\text { moles of converted cyclohexene }} \times 100 \%
\end{gathered}
$$

\section{Results and discussion}

\subsection{Characterization of the PSCSA catalyst}

The FT-IR spectra of the partially carbonized peanut shell and PSCSA are shown in Fig. 1, which identified the functional groups on the carbon surface. Compared to the spectrum of the partially carbonized peanut shell, there were two additional bands at 1189 and $1037 \mathrm{~cm}^{-1}$ in the PSCSA, which were assigned to the $\mathrm{SO}_{2}$ symmetric and asymmetric stretching modes, respectively [36]. This illustrated that sulfonic acid groups were loaded on the surface of the PSCSA by the sulfonation process. Moreover, the band at $1711 \mathrm{~cm}^{-1}$ can be assigned to

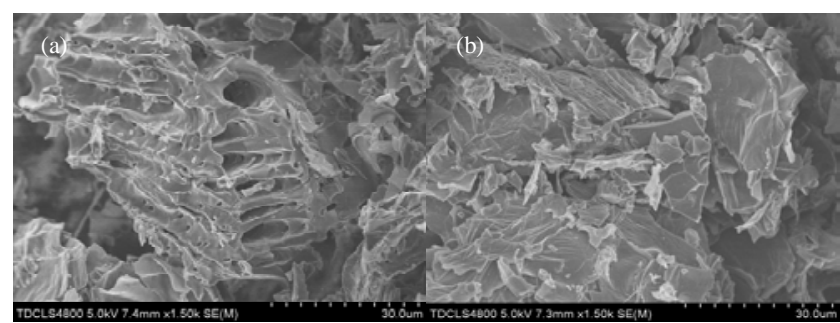

Fig. 2. SEM images of PSCSA.

the $\mathrm{C}=\mathrm{O}$ stretching mode of the $-\mathrm{COOH}$ group [24]. Therefore, $-\mathrm{COOH}$ and $-\mathrm{SO}_{3} \mathrm{H}$ were present on the surface of PSCSA, which became an acidic material with Brönsted acid sites.

Fig. 2 shows the SEM images of the PSCSA catalyst at two different positions. There were two different morphologies seen on this carbon material. Fig. 2(a) shows that the sample has a highly irregular, complex structure with some discrete pores. Part of the sample has an ordered fiber-like structure. Another part of the same sample, shown in Fig. 2(b), has lamellar structures of different sizes. The difference between the different parts of PSCSA was attributed to the inhomogeneous components of the peanut shell. SEM-EDAX tests showed that the $\mathrm{S}$ contents were 3.01 and $3.62 \mathrm{wt} \%$ at the two positions on the PSCSA.

The XRD pattern of PSCSA, shown in Fig. 3(a), exhibited one broad diffraction peak at $10^{\circ}-30^{\circ}$ and one weak peak at $40^{\circ}-50^{\circ}$. The peaks were attributed to amorphous carbon composed of aromatic carbon sheets in random orientations [14]. Okamura et al. [2] showed that the latter peak was due to the $a$ axis of the graphite structure. When using D-glucose as the precursor of the CSAs, the diffraction peak appeared at a higher carbonization temperature, $823 \mathrm{~K}$. Therefore, this showed that peanut shell was easily carbonized and the PSCSA was composed of large carbon sheets. Fig. 3(b) shows the Raman spectrum of the PSCSA catalyst. The intensity ratio of the D band (1350 $\mathrm{cm}^{-1}, \mathrm{~A}_{1 \mathrm{~g}} \mathrm{D}$ breathing mode) to the $\mathrm{G}$ band (1590 $\mathrm{cm}^{-1}, \mathrm{E}_{2 \mathrm{~g}} \mathrm{G}$ mode) was 0.85 . The average size of the graphene in PSCSA was therefore estimated to be $1.2 \mathrm{~nm}$ [37].

The thermal stability of PSCSA was examined by TGA under a flow of air/ $\mathrm{N}_{2}$. The results are shown in Fig. 4. PSCSA lost $10.0 \%$ of its weight from 333 to $393 \mathrm{~K}$, which was due to desorption of water and other low boiling compounds. The
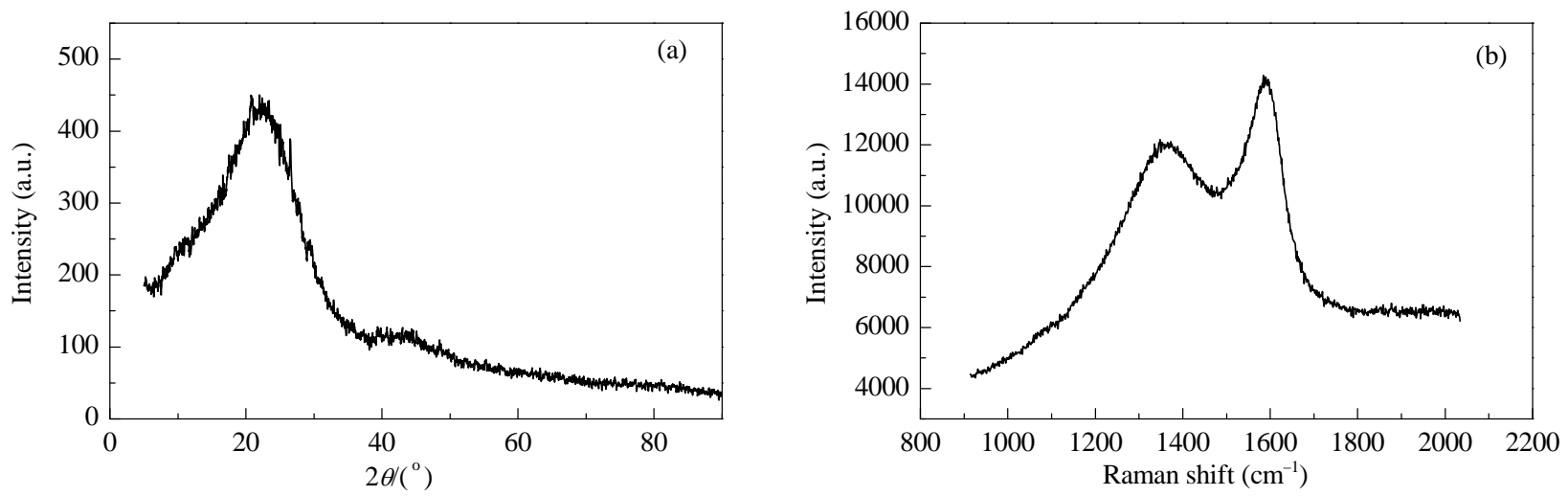

Fig. 3. XRD pattern (a) and Raman spectrum (b) of PSCSA. 


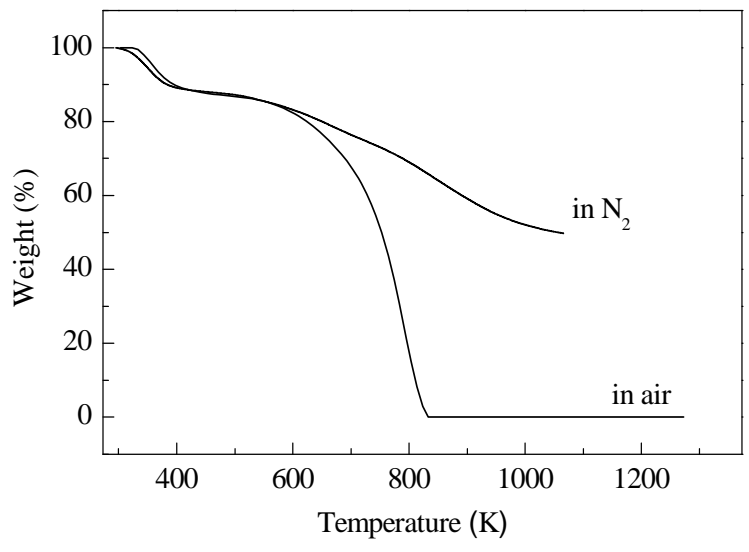

Fig. 4. TGA curves of PSCSA in air/ $\mathrm{N}_{2}$.

weight did not change from 393 to $553 \mathrm{~K}$. A rapid $85.0 \%$ weight loss then occurred from 553 to $823 \mathrm{~K}$ due to the oxidation of the carbon. Hara et al. [1] found by temperature programmed desorption with a mass spectrometer (TPD-MS) that $\mathrm{H}_{2} \mathrm{O}, \mathrm{SO}_{2}$, and $\mathrm{CO}_{2}$ were evolved from a carbon solid acid above $520 \mathrm{~K}$. Because PSCSA was used in an inert atmosphere $\left(\mathrm{N}_{2}\right)$ in this study, the TGA measurement of PSCSA was also conducted in $\mathrm{N}_{2}$. Due to the removal of water, there was a noticeable weight loss of $10.1 \%$ below $393 \mathrm{~K}$, which was similar to the TGA result in air. Then, beyond $498 \mathrm{~K}$, there was a weight loss of $40.1 \%$, which was attributed to the thermal decomposition of $\mathrm{PhSO}_{3} \mathrm{H}$ groups [38]. When the temperature was above the carbonization temperature $(723 \mathrm{~K})$ of PSCSA, there were also weight losses corresponding to the deep carbonization process, such as pyrolysis of lignin and primary carbide [39]. In any event, PSCSA was stable below $473 \mathrm{~K}$, where the esterification of cyclohexene with formic acid was conducted.

Fig. 5 shows the narrow scan for the $S 2 p$ region of the XPS spectrum of the PSCSA catalyst. A single S $2 p$ peak was observed at $168.3 \mathrm{eV}$, which indicated that all the $\mathrm{S}$ atoms in the catalyst were contained in $-\mathrm{SO}_{3} \mathrm{H}$ groups. Thus, the density of $-\mathrm{SO}_{3} \mathrm{H}$ groups can be estimated on the basis of the $\mathrm{S}$ content. The density of $-\mathrm{SO}_{3} \mathrm{H}$ sites in PSCSA was calculated to be 0.81 $\mathrm{mmol} / \mathrm{g}$ with an $\mathrm{S}$ content of $2.59 \mathrm{wt} \%$ as measured by elemental analysis.

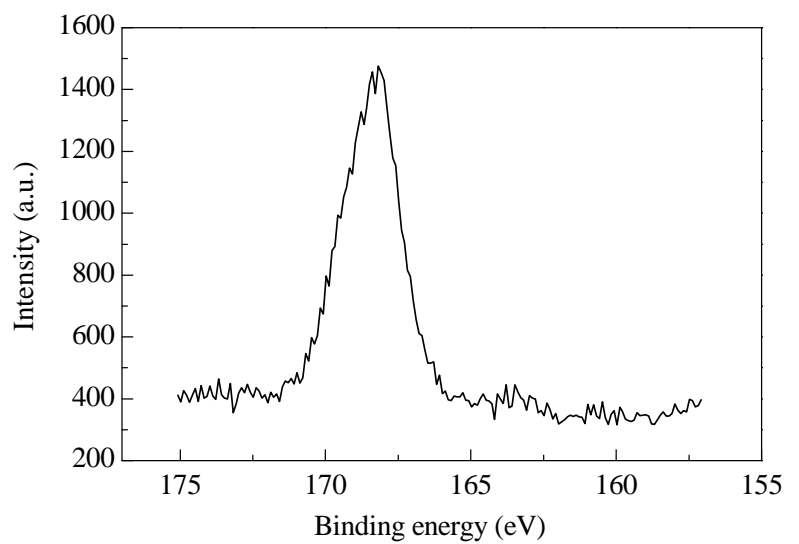

Fig. 5. XPS spectrum of PSCSA.

\subsection{Esterification of cyclohexene with formic acid over PSCSA}

The esterification of cyclohexene with formic acid is an electrophilic addition reaction. First, cyclohexene is protonated by $-\mathrm{SO}_{3} \mathrm{H}$ on PSCSA to generate the carbocation, which is the rate determining step. The carbocation is then attacked by the nucleophilic formic acid molecule to create an oxonium ion. Finally, cyclohexyl formate is formed by deprotonation of the oxonium ion and the catalyst is regenerated. The reaction mechanism is shown in Scheme 1. Besides cyclohexyl formate, the GC analysis also showed that cyclohexanol was the main side product. Since the purity of formic acid used in this work was $99 \%$, there may be a small quantity of water in the reaction. Therefore, cyclohexanol was produced by the hydrolysis of cyclohexyl formate, or the direct hydration of cyclohexene. Moreover, other side products, such as a cyclohexene dimer and dicyclohexyl ether were also found by GC-MS at higher sensitivity. The amounts of these additional products were negligible. Other studies have shown that these side reactions are unavoidable in the reactions of olefins over an acidic catalyst [40]. The overall reactions involved in PSCSA-catalyzed esterification of cyclohexene with formic acid are shown in Scheme 2.

\subsubsection{Effect of the molar ratio of formic acid to cyclohexene}

According to the stoichiometry, equimolar formic acid is needed for cyclohexene to form cyclohexyl formate. Because esterification is a reversible reaction, there must be an excess of formic acid to promote the conversion of cyclohexene. The effect of the molar ratio of formic acid to cyclohexene on this esterification was studied. The results are shown in Fig. 6. When an equimolar amount of formic acid and cyclohexene was used, the cyclohexene conversion was $59.1 \%$. The cyclohexene conversion increased to $87.8 \%$ with a molar ratio of 3 to 1 . It then slightly increased as the molar ratio increased to 5

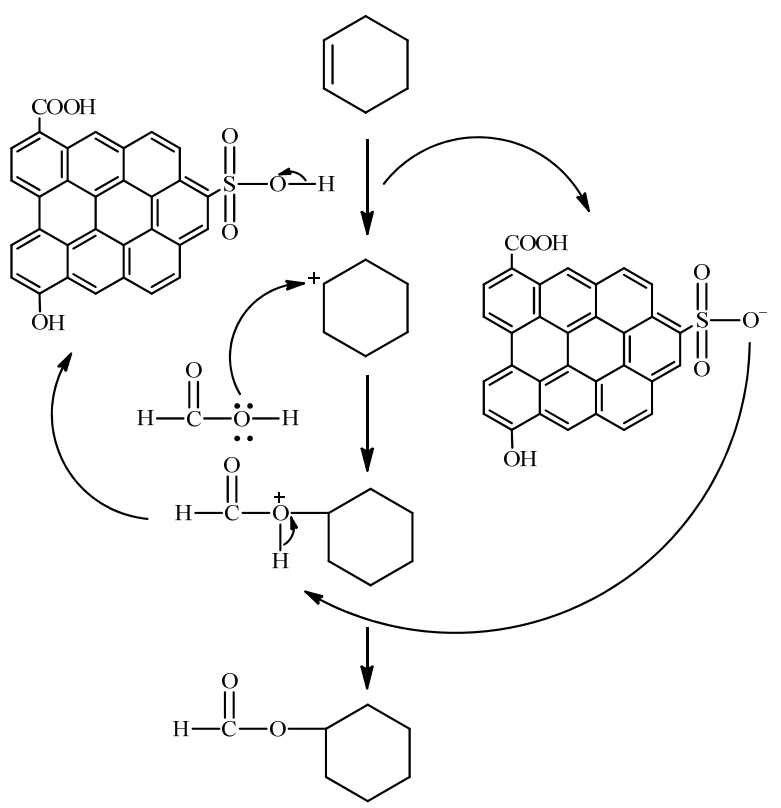

Scheme 1. Mechanism of the esterification of cyclohexene with formic acid over PSCSA. 


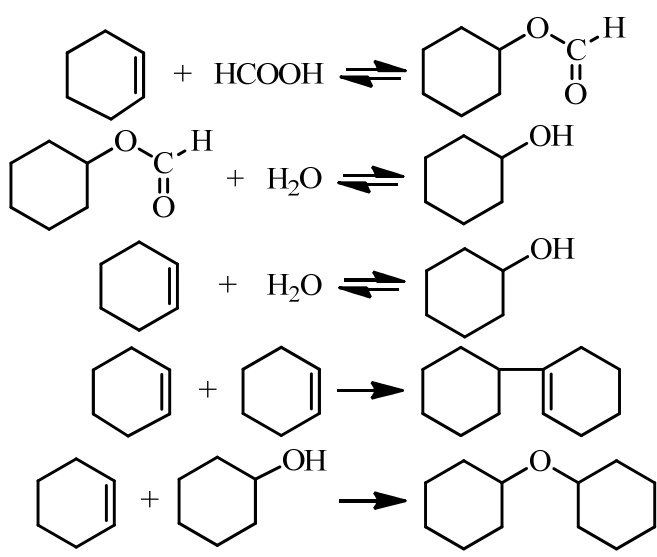

Scheme 2. Reactions in the esterification of cyclohexene with formic acid over a PSCSA catalyst.

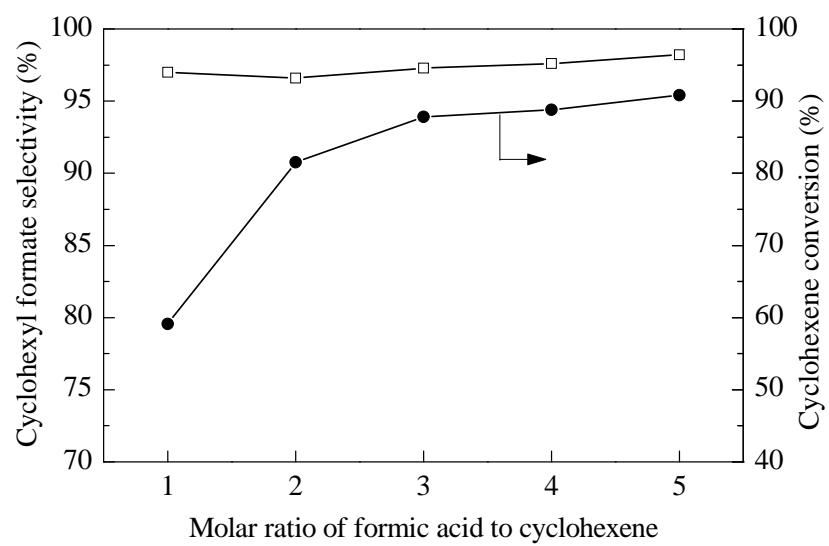

Fig. 6. Effect of the molar ratio of formic acid to cyclohexene on the esterification of cyclohexene with formic acid. Conditions: $413 \mathrm{~K}, 1 \mathrm{~h}$, catalyst loading $0.13 \mathrm{~g} / \mathrm{mL}$-cyclohexene.

to 1 . The selectivity for cyclohexyl formate changed only slightly at different ratios of formic acid to cyclohexene and was always above $96.6 \%$.

\subsubsection{Effect of PSCSA catalyst loading}

The effect of PSCSA catalyst loading on the esterification of cyclohexene with formic acid is shown in Fig. 7. At a catalyst loading of $0.01 \mathrm{~g} / \mathrm{mL}$-cyclohexene, cyclohexene conversion was $70.8 \%$ with $97.9 \%$ selectivity for cyclohexyl formate. On increasing the catalyst loading to $0.07 \mathrm{~g} / \mathrm{mL}$ of cyclohexene, the cyclohexene conversion reached $88.4 \%$. This was because of the increase in the number of acid sites. However, a further increase in the catalyst loading from 0.07 to 0.19 $\mathrm{g} / \mathrm{mL}$-cyclohexene decreased the cyclohexene conversion slightly to $84.9 \%$. One possible reason is that the poor mixing of the reactants caused by the high catalyst loading under the same stirring conditions resulted in a lower reaction rate. The selectivity for cyclohexyl formate also decreased slightly with increased PSCSA catalyst loading. The GC results showed that both of the amounts of cyclohexanol and 1-cyclohexyl cyclohexene increased with increasing catalyst loading. Therefore, the optimum catalyst loading for this experimental system was $0.07 \mathrm{~g} / \mathrm{mL}$-cyclohexene.

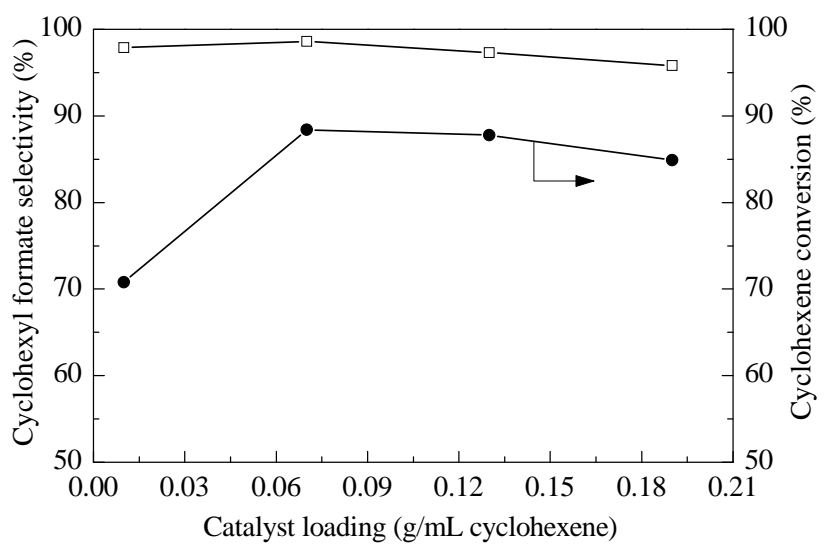

Fig. 7. Effect of catalyst loading on the esterification of cyclohexene with formic acid. Conditions: $413 \mathrm{~K}, 1 \mathrm{~h}$, formic acid-to-cyclohexene molar ratio $3: 1$.

\subsubsection{Effect of reaction temperature}

To study the effect of reaction temperature on the esterification of cyclohexene with formic acid, experiments over the PSCSA catalyst were carried out at 393-433 K. The results are shown in Fig. 8. As the reaction temperature increased from 393 to $413 \mathrm{~K}$, cyclohexene conversion increased rapidly from $39.9 \%$ to $88.4 \%$. However, at higher temperatures, the cyclohexene conversion decreased. At $433 \mathrm{~K}$, the cyclohexene conversion was $79.9 \%$. The selectivity for cyclohexyl formate was almost constant with temperature but also showed an analogous trend of peaking at $413 \mathrm{~K}$.

In general, a higher temperature should give a higher reaction rate. Because esterification of cyclohexene with formic acid is a reversible exothermic reaction, higher temperatures enhance the reverse reaction, which favored the pyrolysis of cyclohexyl formate to cyclohexene and formic acid. In addition, the GC results showed that the amounts of cyclohexanol and 1-cyclohexyl cyclohexene increased with increasing temperature. In other words, a higher temperature promoted the hydrolysis of cyclohexyl formate and the dimerization of cyclohexene. Therefore, cyclohexene conversion and selectivity to cyclohexyl formate both decreased at higher temperatures.

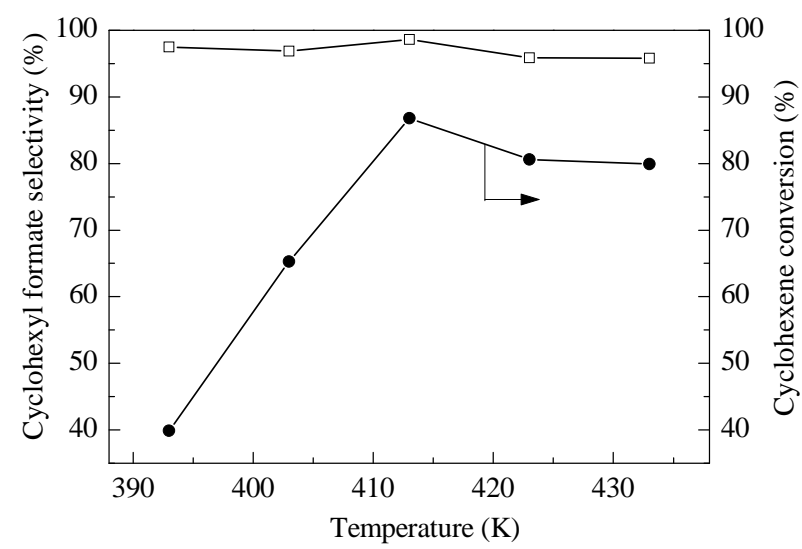

Fig. 8. Effect of the reaction temperature on the esterification of cyclohexene with formic acid. Conditions: $1 \mathrm{~h}$, formic acid-to-cyclohexene molar ratio 3:1, catalyst loading $0.07 \mathrm{~g} / \mathrm{mL}$-cyclohexene. 


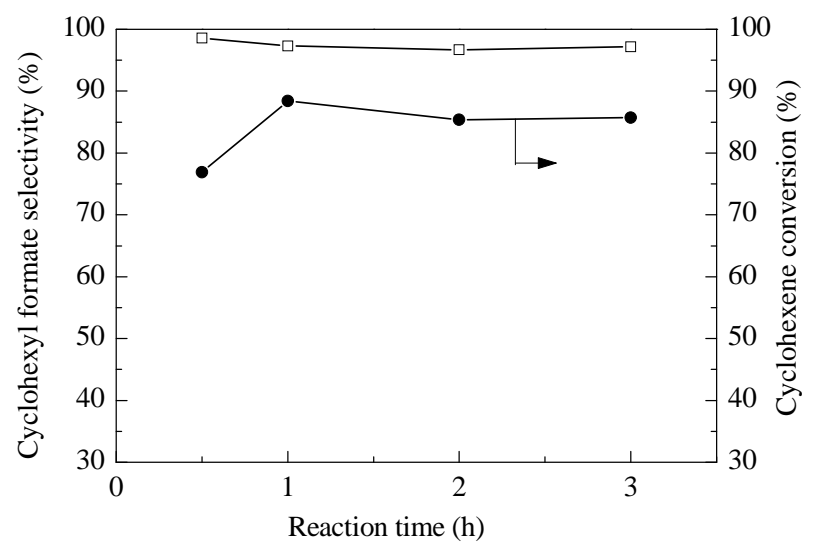

Fig. 9. Effect of reaction time on the esterification of cyclohexene with formic acid. Conditions: $413 \mathrm{~K}$, formic acid-to-cyclohexene molar ratio 3:1, catalyst loading $0.07 \mathrm{~g} / \mathrm{mL}$-cyclohexene.

\subsubsection{Effect of reaction time}

The effect of the reaction time on the esterification of cyclohexene with formic acid is shown in Fig. 9. Cyclohexene conversion was $76.9 \%$ at $0.5 \mathrm{~h}$. This increased to $88.4 \%$ at $1 \mathrm{~h}$. Cyclohexene conversion was then unchanged up to $3 \mathrm{~h}$. The selectivity to cyclohexyl formate decreased slightly as the time increased. This was because the esterification reaction was followed by the hydrolysis of cyclohexyl formate to cyclohexanol. Prolonged reaction times favor the formation of cyclohexanol. However, because of the limited amount of water, the consecutive reaction was limited. Therefore, the optimum reaction time was $1 \mathrm{~h}$ with $88.4 \%$ cyclohexene conversion and $97.3 \%$ selectivity for cyclohexyl formate.

\subsubsection{Comparison of PSCSA with other acid catalysts for the esterification of cyclohexene with formic acid}

The evaluation of catalytic performance for the esterification of cyclohexene with formic acid over several acid catalysts is illustrated in Table 1. Among these catalysts, Amberlyst-15 exhibited the highest activity even when the reaction was conducted at $393 \mathrm{~K}$ due to the limit placed by its maximum operating temperature. This was attributed to its highest acid density. However, its high price limits its large scale application in

Table 1

Catalytic performance in the esterification of cyclohexene with formic acid.

\begin{tabular}{lccccc}
\hline Catalyst & $\begin{array}{c}S_{\mathrm{BET}} \\
\left(\mathrm{m}^{2} / \mathrm{g}\right)\end{array}$ & $\begin{array}{c}\text { Pore } \\
\text { diameter } \\
(\mathrm{nm})\end{array}$ & $\begin{array}{c}\text { Acid } \\
\text { density } \\
(\mathrm{mmol} / \mathrm{g})\end{array}$ & $\begin{array}{c}\text { Cyclohexene } \\
\text { conversion } \\
(\%)\end{array}$ & $\begin{array}{c}\text { Cyclohexyl } \\
\text { formate } \\
\text { selectivity } \\
(\%)\end{array}$ \\
\hline PSCSA & 10.0 & 3.9 & $0.81^{\mathrm{a}}$ & 87.8 & 97.4 \\
HZSM-5 b & 416.1 & 0.57 & $1.70^{\mathrm{c}}$ & 77.6 & 97.0 \\
Amberlyst-15 $^{\mathrm{d}}$ & 42.3 & - & 4.60 & 91.5 & 98.1 \\
Nafion NR50 $^{\mathrm{n}}$ & $<1$ & - & 0.51 & 68.2 & 98.5 \\
\hline
\end{tabular}

Reaction conditions: $413 \mathrm{~K}, 1 \mathrm{~h}$, catalyst loading $0.13 \mathrm{~g} / \mathrm{mL}$-cyclohexene, formic acid/cyclohexene 3:1 (molar ratio).

a Based on $\mathrm{S}$ content by elemental analysis.

b $n\left(\mathrm{SiO}_{2}\right) / n\left(\mathrm{Al}_{2} \mathrm{O}_{3}\right)=25$.

c Measure by $\mathrm{NH}_{3}$-TPD.

${ }^{\mathrm{d}}$ Purchased from Alfa; reaction was condcuted at $393 \mathrm{~K}$.

e Purchased from Alfa.

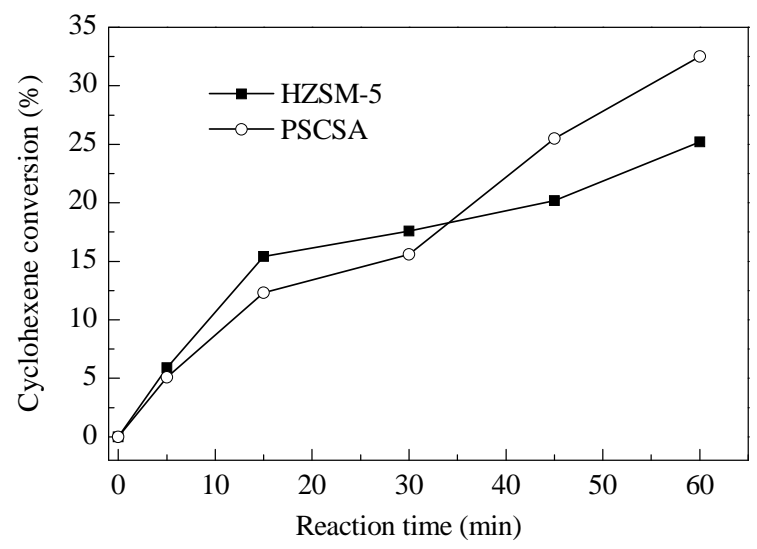

Fig. 10. Comparison of PSCSA with HZSM-5 for the esterification of cyclohexene with formic acid. Conditions: $393 \mathrm{~K}$, formic acid-to-cyclohexene molar ratio 3:1, catalyst loading $0.01 \mathrm{~g} / \mathrm{mL}$-cyclohexene.

industry. PSCSA showed the second highest catalytic activity although both the specific surface area and acid density of PSCSA were less than those of HZSM-5. To have a better comparison between these two catalysts, the chemical reaction rate at the initial stage was investigated. Fig. 10 shows the cyclohexene conversion over PSCSA and HZSM-5 at $393 \mathrm{~K}$. At the initial stage, the reaction rate over HZSM-5 was a little faster than that over PSCSA. After the reaction had proceeded for 30 min, cyclohexene conversion over PSCSA increased rapidly, which indicated a faster reaction rate.

Both the high activity of PSCSA and the change in the reaction rate can be explained by one of the properties of PSCSA, which is that it swells in a strongly polar solvent. Kitano et al. [14] found that the carbon solid acid swelled in water and the effective surface area determined from the water vapor adsorption isotherm was as high as $580 \mathrm{~m}^{2} / \mathrm{g}$. Therefore, in this reaction, PSCSA swelled in the formic acid solvent and incorporated a large amount of formic acid into the carbon bulk. Because cyclohexene and formic acid have good miscibility, cyclohexene can be incorporated into the carbon particles to reach the $-\mathrm{SO}_{3} \mathrm{H}$ active sites easily with the help of formic acid. This resulted in the good catalytic performance of PSCSA. Furthermore, Zeng et al. [24] found that the acid strength of the solid acid from peanut shell was stronger than that of HZSM-5 $(\mathrm{Si} / \mathrm{Al}=75)$. This was also an important reason for the high activity of PSCSA. The difference in the pore size of the two catalysts also has an effect. As shown in Table 1, the average pore diameter of PSCSA (3.9 $\mathrm{nm}$ ) was larger than that of the HZSM-5 (0.57 nm). Therefore, PSCSA would have faster molecular internal diffusion than HZSM-5. The different reaction rate over PSCSA may also be attributed to the swelling. At first, PSCSA did not swell fully, therefore the number of the active sites that cyclohexene and formic acid can reach was limited. After the reaction had proceeded for a while, PSCSA had swelled completely and the active sites that take part in the reaction increased. Therefore, the reaction was accelerated.

\subsubsection{Reusability of PSCSA}

The reusability of the PSCSA catalyst for the esterification of cyclohexene with formic acid was investigated. The catalyst 


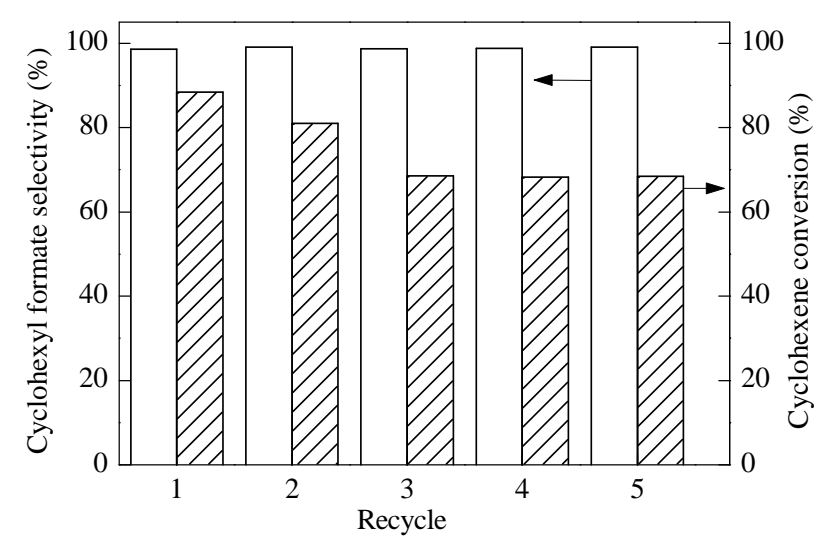

Fig. 11. Reusability of the PSCSA catalyst.

was filtered from the mixture after the reaction and washed with water and dried. Then, it was reused directly in a new cycle without any further treatment. As shown in Fig. 11, high selectivity for cyclohexyl formate was obtained in every cycle, but the cyclohexene conversion decreased from $88.4 \%$ to $81.0 \%$ ( 2 nd cycle) to $68.6 \%$ ( $3 \mathrm{rd}$ cycle). After this, the activity remained constant with reuse from the 3 rd to the 5 th cycles.

When the HZSM-5 zeolite catalyst was used in this reaction, it also showed a decline in the reusability tests [35]. The reason for the deactivation of HZSM-5 is the covering of the acid sites and diffusion hindrance by the accumulation of oligomerized cyclohexene in the zeolite micropores. The PSCSA catalyst has a smaller specific surface area and there were almost no micropores. Therefore, the deposition of macromolecular compounds was not the reason for the decline in activity. The PSCSA catalyst that had been used for five cycles was characterized and the $-\mathrm{SO}_{3} \mathrm{H}$ density was only $0.55 \mathrm{mmol} / \mathrm{g}$. Compared with that on the fresh PSCSA of $0.81 \mathrm{mmol} / \mathrm{g}$, it was concluded that the activity decrease was proportional to the decrease of the $-\mathrm{SO}_{3} \mathrm{H}$ density and the deactivation of PSCSA was due to the leaching of $-\mathrm{SO}_{3} \mathrm{H}$.

Although sulfonated carbons are insoluble in some solvents [2], Mo et al. [41] found that the catalytic deactivation of their CSAs was caused by the leaching of polycyclic aromatic hydrocarbon-containing - $\mathrm{SO}_{3} \mathrm{H}$ groups, especially in polar media. This phenomenon that the PSCSA catalytic activity decreased in the initial cycles but then was constant after three cycles indicated that the leaching of the active species on the PSCSA had stopped. This was attributed to the different nature of the acid sites. Some were readily leached, while others were not. Mo et al. [41] estimated that $75 \%-80 \%$ of the acid sites in a sulfonated carbon catalyst were more stable and not readily leached. This is in accordance with our reusability tests.

\section{Conclusions}

A peanut shell-derived carbon solid acid exhibited high activity for the esterification of cyclohexene with formic acid. At the optimal reaction conditions of reaction for $1 \mathrm{~h}$ at $413 \mathrm{~K}$, formic acid-to-cyclohexene molar ratio of $3: 1$, and catalyst loading of $0.07 \mathrm{~g} / \mathrm{mL}$ of cyclohexene, the cyclohexene conver- sion was $88.4 \%$ with $97.3 \%$ selectivity for cyclohexyl formate. Compared to HZSM-5, the catalyst showed better activity because of fast adsorption of both reactants which was due to the swelling of this catalyst in formic acid. The initial decrease of catalytic activity in the first two recycles was due to the leaching of polycyclic aromatic hydrocarbon containing $-\mathrm{SO}_{3} \mathrm{H}$ groups. Because of the different nature of the acid sites, the leaching stopped and the catalytic activity remained stable in the succeeding reuse.

\section{References}

[1] M. Hara, T. Yoshida, A. Takagaki, T. Takata, J. N. Kondo, S. Hayashi, K. Domen, Angew. Chem. Int. Ed., 2004, 43, 2955-2958.

[2] M. Okamura, A. Takagaki, M. Toda, J. N. Kondo, K. Domen, T. Tatsumi, M. Hara, S. Hayashi, Chem. Mater., 2006, 18, 3039-3045.

[3] T. T. Liu, Z. L. Li, W. Li, C. J. Shi, Y. Wang, Bioresour. Technol, 2013, 133, 618-621.

[4] L. Geng, G. Yu, Y. Wang, Y. X. Zhu, Appl. Catal. A, 2012, 427-428, 137-144.

[5] M. H. Zhang, A. X. Sun, Y. L. Meng, L. T. Wang, H. X. Jiang, G. M. Li, Microporous Mesoporous Mater., 2015, 204, 210-217.

[6] C. A. Deshmane, M. W. Wright, A. Lachgar, M. Rohlfing, Z. N. Liu, J. Le, B. E. Hanson, Bioresour. Technol., 2013, 147, 597-604.

[7] I. M. Lokman, U. Rashld, Y. H. Taufiq-Yap, Chem. Eng. Technol., 2015, 38, 1837-1844.

[8] A. M. Dehkhoda, A. H. West, N. Ellis, Appl. Catal. A, 2010, 382, 197-204.

[9] C. X. Wang, F. L. Yuan, L. J. Liu, X. Y. Niu, Y. J. Zhu, ChemPlusChem, 2015, 80, 1657-1665.

[10] L. Z. Cai, D. C. Meng, S. Q. Zhan, X. X. Yang, T. P. Liu, H. M. Pu, X. C. Tao, RSC Adv., 2015, 5, 72146-72149.

[11] K. Nakajima, M. Hara, S. Hayashi, J. Am. Ceram. Soc., 2007, 90, 3725-3734.

[12] J. J. Wang, W. J. Xu, J. W. Ren, X. H. Liu, G. Z. Lu, Y. Q. Wang, Green Chem., 2011, 13, 2678-2681.

[13] L. N. Zhou, K. Liu, W. M. Hua, Y. H. Yue, Z. Gao, Chin. J. Catal., 2009, 30, 196-200.

[14] M. Kitano, D. Yamaguchi, S. Suganuma, K. Nakajima, H. Kato, S. Hayashi, M. Hara, Langmuir, 2009, 25, 5068-5075.

[15] D. Yamaguchi, M. Hara, Solid State Sci., 2010, 12, 1018-1023.

[16] S. Suganuma, K. Nakajima, M. Kitano, D. Yamaguchi, H. Kato, S. Hayashi, M. Hara, J. Am. Chem. Soc., 2008, 130, 12787-12793.

[17] S. G. Shen, B. Cai, C. Y. Wang, H. M. Li, G. Dai, H. F. Qin, Appl. Catal. A, 2014, 473, 70-74.

[18] A. Zali, K. Ghani, A. Shokrolahi, M. H. Keshavarz, Chin. J. Catal., 2008, 29, 602-606.

[19] K. Nakajima, I. Tomita, M. Hara, S. Hayashi, K. Domen, J. N. Kondo, Catal. Today, 2006, 116, 151-156.

[20] Y. X. Liu, Y. Y. Fang, X. L. Lu, Z. J. Wei, X. N. Li, Chem. Eng. J., 2013, 229, 105-110.

[21] K. Nakajima, M. Hara, ACS Catal., 2012, 2, 1296-1304.

[22] W. Q. Zhao, B. L. Yang, C. H. Yi, Z. Lei, J. Xu, Ind. Eng. Chem. Res., 2010, 49, 12399-12404.

[23] Y. Wu, B. Li, J. F. Hu, J. N. Chen, X. S. Zheng, L. B. Wen, Petrochem. Technol., 2009, 38, 240-243.

[24] D. L. Zeng, S. L. Liu, W. J. Gong, G. H. Wang, J. H. Qiu, H. X. Chen, Appl. Catal. A, 2014, 469, 284-289.

[25] G. D. Yadav, P. K. Goel, Green Chem., 2000, 2, 71-77.

[26] B. Saha, M. M. Sharma, React. Funct. Polym., 1996, 28, 263-278.

[27] H. B. Zhang, W. Tong, W. P. Xin, H. X. Li, Chin. J. Catal., 1995, 16, 


\title{
Graphical Abstract
}

Chin. J. Catal., 2016, 37: 769-777 doi: 10.1016/S1872-2067(15)61076-2

\section{Esterification of cyclohexene with formic acid over a peanut shell-derived carbon solid acid catalyst}

Wei Xue, Hepan Zhao, Jie Yao, Fang Li *, Yanji Wang *

Hebei University of Technology

A peanut shell-derived carbon solid acid (PSCSA) gave high cyclohexene conversion with high selectivity and good reusability in the esterification of cyclohexene with formic acid.

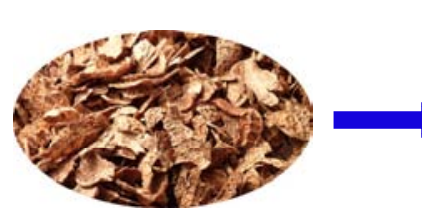

Peanut shell

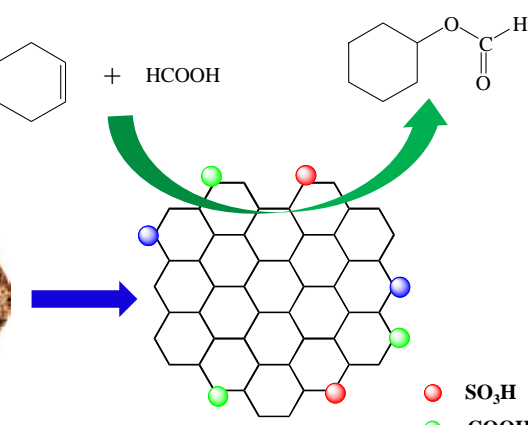

- $\mathbf{C O O H}$

PSCSA

○ $\mathbf{~ O H}$
387-391.

[28] Y. L. Gu, F. Shi, Y. Q. Deng, J. Mol. Catal. A, 2004, 212, 71-75.

[29] F. Zhou, J. H. Tang, Z. Y. Fei, X. L. Zhou, X. Chen, M. F. Cui, M. Qiao, J. Porous Mater., 2014, 21, 149-155.

[30] F. Steyer, K. Sundmacher, Ind. Eng. Chem. Res., 2007, 46, 10991104.

[31] S. J. Lou, C. X. Xiao, G. Sun, Y. Kou, Chin. J. Catal., 2013, 34, 251-256.

[32] H. Nagahara, M. Ono, M. Konishi, Y. Fukuoka, Appl. Surf. Sci., 1997 121-122, 448-451.

[33] R. Ahamed Imam, H. Freund, R. P. M. Guit, C. Fellay, R. J. Meier, K. Sundmacher, Org. Process. Res. Dev., 2013, 17, 343-358.

[34] A. Katariya, H. Freund, K. Sundmacher, Ind. Eng. Chem. Res., 2009
48, 9534-9545.

[35] W. M. Du, W. Xue, F. Li, Y. J. Wang, J. Hebei Univ. Technol., 2012, 41(4), 34-39.

[36] L. Geng, Y. Wang, G. Yu, Y. X. Zhu, Catal. Commun., 2011, 13, 26-30.

[37] A. C. Ferrari, J. Robertson, Phys. Rev. B, 2000, 61, 14095-14107.

[38] X. Y. Liu, M. Huang, H. L. Ma, Z. Q. Zhang, J. M. Gao, Y. L. Zhu, X. J. Han, X. Y. Guo, Molecules, 2010, 15, 7188-7196.

[39] L. T. Wang, X. Q. Dong, H. X. Jiang, G. M. Li, M. H. Zhang, Bioresour. Technol., 2014, 158, 392-395.

[40] H. Ishida, Catal. Surv. Jpn., 1997, 1, 241-246.

[41] X. H. Mo, D. E. López, K. Suwannakarn, Y. J. Liu, E. Lotero, J. G. Goodwin Jr., C. Q. Lu, J. Catal., 2008, 254, 332-338.

\section{花生壳碳基固体酸催化环己烯与甲酸酯化反应}

\author{
薛 伟, 赵贺潘, 姚 洁, 李 芳*, 王延吉 ${ }^{*}$
}

河北工业大学化工学院, 河北省绿色化工与高效节能重点实验室, 天津 300130

摘要: 碳基固体酸是一种可替代液体质子酸的无定形碳材料, 具有酸密度大、催化活性高等优点. 花生壳是农业废弃物, 以 其为原料制备碳基固体酸具有成本低、原料可再生和环境友好等优点. 甲酸环己酯是重要的化工产品, 可用于香料和涂料 工业. 传统的甲酸环己酯制备方法是以环己醇和甲酸为原料, 在酸催化条件下进行酯化反应而得. 近年来, 随着环己烯的 大规模生产, 利用环已烯与甲酸直接酯化制备甲酸环己酯引起广泛关注. 此外, 甲酸环己酯还可通过水解反应转变为环己 醇. 环己醇可以进一步转化为己二酸和己内酰胺, 从而用于化纤工业中尼龙-6 和尼龙-66 的生产. 目前, 工业上采用环己烯 水合反应制备环己醇, 由于热力学限制, 并受到环己烯与水相容性差的影响, 环己烯单程转化率仅为 $10 \%$, 循环量较大, 能 耗很高. 以环己烯为原料, 通过甲酸环己酯制备环己醇克服了上述环己烯直接水合的缺点, 具有很好的发展前景. 我们研 究组使用 HZSM-5 分子篮作为催化剂, 采用“一锅法” 由环已烯经甲酸环己酯制备环己醇, 环己醇收率可达 $40 \%$. 但是环己 烯在酸性条件下可发生低聚反应,生成的副产物会堵塞 HZSM-5 孔道, 造成催化剂失活.

本文在前述研究基础上, 以花生壳为原料, 经过碳化、磺化过程制备得到了碳基固体酸 PSCSA. 采用傅里叶变换红外 光谱 (FT-IR)、扫描电子显微镜 (SEM)、X 射线衍射 (XRD)、拉曼光谱 (Raman)、热重分析 (TG)、X 射线光电子能谱 (XPS) 和元素分析等方法表征了 PSCSA 的结构、微观形貌、热稳定性以及酸性质, 考察了其催化环己烯与甲酸酯化反应性能, 并 与几种常见的固体酸催化剂进行了比较.

FT-IR 结果显示, 经磺化后, PSCSA 表面出现了 $-\mathrm{SO}_{3} \mathrm{H}$ 和-COOH 基团. XPS 结果则说明 PSCSA 表面所有的 S 元素均 属于 $-\mathrm{SO}_{3} \mathrm{H}$, 可利用元素分析测定 $\mathrm{S}$ 含量, 进而得到 $-\mathrm{SO}_{3} \mathrm{H}$ 密度. 此外, 由于花生壳属于天然物质, 成分并不均一, 因此 PSCSA 的 SEM 照片中不同部位颗粒的微观形貌差异较大. 采用 PSCSA 作为催化剂, 考察了其催化环已烯与甲酸酯化反 应性能, 优化了反应条件. 在酸烯摩尔比为 3/1, PSCSA 用量 $0.07 \mathrm{~g} / \mathrm{mL}$ 环己烯, $413 \mathrm{~K}$ 反应 $1 \mathrm{~h}$, 环已烯转化率为 $88.4 \%$, 甲 酸环己酯选择性为 97.3\%; 副产物包括环己醇、二聚环己烯和环己基醚等. 比较了 PSCSA 与几种常用固体酸如 HZSM-5、 离子交换树脂 Amberlyst-15 和 Nafion NR50 的催化性能, 其中, Amberlyst-15 催化性能最优, 在 393 K 下反应, 环己烯转化 
率亦达 91.5\%, 甲酸环己酯选择性 98.1\%; 但是, 高昂的价格限制了其在工业上的大规模应用. 与 HZSM-5 相比, PSCSA 催 化的环己烯与甲酸酯化反应的初始速率较低, 反应时间超过 $30 \mathrm{~min}$ 后, 环己烯转化率迅速增加. 在本反应中, PSCSA 在甲 酸存在条件下发生溶胀, 使得大量的甲酸分子插入到碳材料本体中; 而环己烯与甲酸具有较好的相容性, 因此环己烯可以 进入到碳材料本体中, 与活性中心 $-\mathrm{SO}_{3} \mathrm{H}$ 充分接触, 从而具有较高的反应速率. 并且, 由于溶胀需要一定的时间, 在反应初 期溶胀不充分时, 环己烯、甲酸与活性中心接触有限, 因此反应较慢; 反应一定时间后, PSCSA 充分溶胀, 更多的- $\mathrm{SO}_{3} \mathrm{H}$ 参 与到反应中, 反应速率加快. PSCSA 重复使用性较好, 第 3 次使用时环己烯转化率为 $68.6 \%$; 继续使用, 催化剂不再失活. PSCSA 在反应初期失活是 $-\mathrm{SO}_{3} \mathrm{H}$ 流失造成的. 构成 PSCSA 的多环芳香烃可以部分溶解到溶剂中, 进而带走其包含的 $-\mathrm{SO}_{3} \mathrm{H}$. PSCSA 的后期活性稳定则说明可以流失的活性中心是有限的.

关键词: 碳基固体酸; 花生壳; 环己烯; 酯化; 甲酸环己酯

收稿日期: 2015-12-21. 接受日期: 2016-02-26. 出版日期: 2016-05-05.

*通讯联系人. 电话: (022)60203540; 传真: (022)60204697; 电子信箱: lifang@hebut.edu.cn

\#通讯联系人. 电话: (022)60202419; 传真: (022)60204697; 电子信箱: yjwang@hebut.edu.cn

基金来源：国家自然科学基金 (21236001，21176056); 河北省高校百名优秀创新人才项目(II)(BR2-208); 河北省自然科学基金 (B2015202228).

本文的英文电子版由Elsevier出版社在ScienceDirect上出版(http://www.sciencedirect.com/science/journal/18722067). 